\title{
HIGH PREVALENCE OF GB VIRUS C/HEPATITIS G VIRUS RNA AMONG BRAZILIAN BLOOD DONORS
}

\author{
José Eduardo LEVI(1,2,4), Daniela Gazoto CONTRI(2), Liliam Pereira LIMA(1), Deise Tihe TAKAOKA(2), Regina Helena GARRINI(2), \\ Wellingtom SANTOS(2), Roberta FACHINI(1,2) \& Silvano WENDEL(1,2,3)
}

\begin{abstract}
SUMMARY
The aim of this study was to investigate the presence of the Hepatitis G Virus on a population of blood donors from São Paulo, Brazil and to evaluate its association to sociodemographic variables. Two RT-PCR systems targeting the putative 5'NCR and NS3 regions were employed and the former has shown a higher sensitivity.

The observed prevalence of HGV-RNA on 545 blood donors was 9.7\% (CI 95\% 7.4;12.5). Statistical analysis depicted an association with race/ethnicity, black and mulatto donors being more frequently infected; and also with years of education, less educated donors presenting higher prevalences. No association was observed with other sociodemographic parameters as age, gender, place of birth and of residence.
\end{abstract}

DNA sequencing of nine randomly chosen isolates demonstrated the presence of genotypes 1,2 and 3 among our population but clustering of these Brazilian isolates was not detected upon phylogenetic analysis.

KEYWORDS: Hepatitis G Virus; HGV; Blood donors; PCR.

\section{INTRODUCTION}

Hepatitis G Virus is a recently identified single-stranded RNA virus that has been detected on blood transfusion recipients and further on other groups presenting parenteral risk factors. It has been classified into the Flaviviridae family sharing a similar genomic arrangement to other members including the Hepatitis C Virus (HCV). The worldwide prevalence of $\mathrm{HGV}$ on healthy populations is notably high, ranging from $2 \%$ on German blood donors ${ }^{15}$ to $14.2 \%$ on West African residents ${ }^{5}$. Sequence analysis has allowed the classification of $\mathrm{HGV}$ isolates on types and this approach revealed the existence of at least 4 genotypes. Genotype 1 is detected mainly on African residents, genotype 2 is the most prevalent on Europe and North America and genotypes 3 and 4 in Asia $^{10,11}$. A fifth South African genotype has also been proposed ${ }^{18}$. Though HGV transmission by blood transfusion is firmly established ${ }^{1}$, several lines of evidence (reviewed in $\mathrm{KLEINMAN}^{7}$ ) led to the conclusion that HGV does not cause any form of liver disease, precluding the need of screening in the blood transfusion setting. The aim of this study was to investigate the presence of the Hepatitis G Virus on a population of blood donors from São Paulo, Brazil and to evaluate its association to sociodemographic variables.

\section{METHODS}

Study population: Serum samples were obtained from 545 consecutive voluntary blood donors from the Hospital Sírio-Libanês Blood Bank (from August to November of 1997), including 380 males and 165 females, ranging from 18 to 59 years of age. All samples were routinely assessed for serological markers, namely; anti-HIV1/2, HBsAg, anti-HBc, anti-HCV, anti-HTLV-I/II, ALT levels, Syphilis and Chagas disease. Demographic data, including age, gender, marital status, race, local of birth and residence and educational background were obtained from donors by self-assessment.

HGV RT-PCR: RNA was extracted from $250 \mu \mathrm{L}$ of serum by the use of TRI Reagent LS (GIBCO BRL, São Paulo, Brazil) in accordance with the manufacturer instructions. Total isolated RNA was submitted to reverse transcription with Random Primers $2.5 \mu \mathrm{M}$ (GIBCO BRL, São Paulo, Brazil) and 50 units of Moloney Murine Leukemia Virus Reverse Transcriptase (M-MLV RT, GIBCO BRL, São Paulo, Brazil) in a volume of $20 \mu \mathrm{L}$, for 30 minutes at $37{ }^{\circ} \mathrm{C}$ followed by 5 minutes at $95{ }^{\circ} \mathrm{C}$. The putative HGV 5' non-coding region was amplified from $5.0 \mu \mathrm{L}$ of cDNA, corresponding to $62.5 \mu \mathrm{L}$ of serum, in a single-round PCR, using antisense primer ( 5 ' CAC TGG GTG CAA GCC CCA GAA 3'), sense primer ( 5' CAC TGG TCC TTG TCA ACT CGC 3') ${ }^{9}$ and one unit of Taq DNA Polymerase (GIBCO BRL, São Paulo, Brazil) in a final volume of $25 \mu \mathrm{L}$. Denaturation at $95{ }^{\circ} \mathrm{C}$ for 5 minutes was followed by 40 cycles of amplification at $94{ }^{\circ} \mathrm{C}$ for $30 \mathrm{~s}, 55^{\circ} \mathrm{C}$ for 30 s and $72{ }^{\circ} \mathrm{C}$ for 1 minute. On positive samples, a PCR product of $367 \mathrm{bp}$ was detectable after electrophoresis on an ethidium bromide stained, $1.8 \%$ agarose gel.

(1) Hospital Sírio-Libanês Blood Bank, São Paulo, SP, Brazil.

(2) Centro de Imunologia e Imunogenética, São Paulo, SP, Brazil.

(3) Post-Graduate Student, Infectious Diseases Department, Faculdade de Medicina da Universidade de São Paulo (FMUSP), São Paulo, SP, Brazil.

(4) Virology Lab., Instituto de Medicina Tropical da Universidade de São Paulo, São Paulo, SP, Brazil.

Correspondence to : Dr. Silvano Wendel, Rua Adma Jafet 91, 01308-050 São Paulo, SP, Brazil, Phone + 551132557746 , Fax + 551132571290 , e-mail : snwendel@ uninet.com.br 


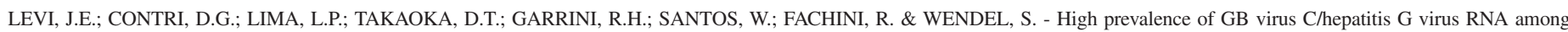
Brazilian blood donors. Rev. Inst. Med. trop. S. Paulo, 45(2):75-78, 2003.

Samples were also submitted to amplification of a distinct HGV genomic region, the NS3 gene, presumably coding for a viral helicase/ protease, using a nested PCR protocol ${ }^{12}$. For the first round, $2.5 \mu \mathrm{L}$ of cDNA was submitted to PCR using antisense primer 1 (5' CGA AGT TTC CTG TGT ACC C 3'), sense primer 1 (5' GAC GTT GGT GAG ATC CCC TT 3') in a final volume of $12.5 \mu \mathrm{L}$. For the second round $5.0 \mu \mathrm{L}$ of first round PCR product was amplified using antisense primer 2 (5' TAG AGA GCG CGT CTG TCG CAC 3') and sense primer 2 (5' TGG GCA TGG TAT CCC CCT CGA GC 3') in a final volume of 25 $\mu \mathrm{L}$. For both rounds, denaturation at $95{ }^{\circ} \mathrm{C}$ for 5 minutes was followed by 40 cycles of $94{ }^{\circ} \mathrm{C}$ for $45 \mathrm{~s}, 53{ }^{\circ} \mathrm{C}$ for $45 \mathrm{~s}$ and $72{ }^{\circ} \mathrm{C}$ for $75 \mathrm{~s} .238 \mathrm{bp}$ and $196 \mathrm{bp}$ were respectively first and second round PCR products detectable after eletrophoresis on an ethidium bromide stained, 1.8\% agarose gel. Positive controls consisted of a $\mathrm{HGV}$ positive sample derived from a chronic hepatitis $\mathrm{C}$ patient and a plasmid containing HGV cloned sequences gently provided by Dr Jason Pickering (Imperial College, Dept. of Medicine, London, UK). Negative controls consisted of plasma supernatant derived from a donation negative for all serological markers plus HCV-RNA and HGV-RNA by the methods described above.

Sequencing: PCR products from 9 randomly chosen isolates (HGV 5 ' non-coding region PCR products) were purified on an ultrafiltration system MICROCON - 100 (AMICON, INC., Beverly, USA) and subjected to direct sequencing by using ABI PRISM Dye terminator Cycle Sequencing Ready reaction kit (Perkin-Elmer, Foster City, USA). Sequences were determined by using automated sequencer ABI 377 (ABI, Foster City, USA) equipment at the DNA Sequencing Core - University of Michigan.

Phylogenetic Analysis: Similarity of the isolates here described to other HGV sequences was verified by a GenBank searching algorithm (BLAST version 2.0 program), available through the National Center for Biotechnology Information Web site (http://www.ncbi.nlm.nih.gov/ ). DNA sequences representative of distinct HGV groups were obtained from the GenBank and aligned with the sequences here reported by using CLUSTAL-W ${ }^{17}$ software (http://dot.imgen.bcm.tmc.edu:9331/multialign/multi-align.html). An unrooted phylogenetic tree was constructed based on the neighbor-joining analysis of the sequence distance data by using the NEIGHBOR program of the PHYLIP package available through the Web site (ftp://evolution.genetics.washington.edu/pub/phylip).

Statistical Analysis: The $\chi^{2}$ or $\chi^{2}$ for trend tests were used for investigating the association between two categorical variables. The odds ratio (OR) for the presence of HGV-RNA considering as exposure several sociodemographic variables was estimated by the method of MantelHaenzel $^{6}$ with confidence intervals of $95 \%$.

\section{RESULTS}

HGV-RNA was detected on 53 out of 545 serum samples $(9.7 \%$, $95 \%$ CI $7.4 ; 12.5)$, by at least one of the two primers sets. Among the $\mathrm{HGV}$ infected individuals, there was no reactivity to the following serological markers: HBsAg, anti-HCV, Syphilis, Chagas disease, HIVp24Ag and anti-HIV 1/2 (Table 1). Of the 53 reactive samples, 47 and 30 were respectively reactive to 5 ' non-coding region and to NS-3 primer pairs while 24 were reactive for both (Table 2 ). There were no significant associations between presence of HGV-RNA with gender ( $p$ $=0.20)$ nor age $(\mathrm{p}=0.15)$. The relative frequency of HGV-RNA was
Table 1

Other serological markers on the donors study population

\begin{tabular}{ccc}
\hline Marker & Repeatedly reactive $(\%)$ & HGV-RNA + \\
\hline anti-HIV ${ }^{1 / 2}$ & $1(0.18)$ & - \\
anti-HBc & $19(3.5)$ & 1 \\
anti-HCV & $2(0.37)$ & - \\
anti-HTLV I/II & $3(0.55)$ & 1 \\
HBsAg & $2(0.4)$ & - \\
ALT* $^{*}$ & $8(1.5)$ & 1 \\
Eletr. Hb $^{@}$ & $7(1.3)$ & 1 \\
Chagas $_{\text {Syphilis }}$ & - & - \\
\hline Total & $2(0.4)$ & $53(9.7 \%)$ \\
\hline
\end{tabular}

*ALT value > 110U/L; @ Anomalous hemoglobin electrophoresis

Table 2

Correlation between primer pairs targeting the Ns3 and the 5'non-coding region

\begin{tabular}{clccc}
\hline & & & NS3 & \\
& & Positive & Negative & Total \\
\hline \multirow{2}{*}{ 5’NCR } & Positive & 24 & 23 & 47 \\
& Negative & 6 & 492 & 498 \\
\hline \multirow{2}{*}{} & Total & 30 & 515 & 545 \\
\hline
\end{tabular}

higher on donors of Negro/Mulatto race $(26.5 \%)$ than on Caucasians $(7.5 \%)$ and Orientals $(0 \%)$ (Fig. 1$)(\mathrm{OR}=4.5,95 \%$ CI 2.3;8.5, Table 3$)$. DNA sequences comparison revealed, on all cases, more than $90 \%$ of sequence identity to other HGV isolates previously described and phylogenetic analysis doesn't show a cluster of Brazilian samples (Fig. 2).

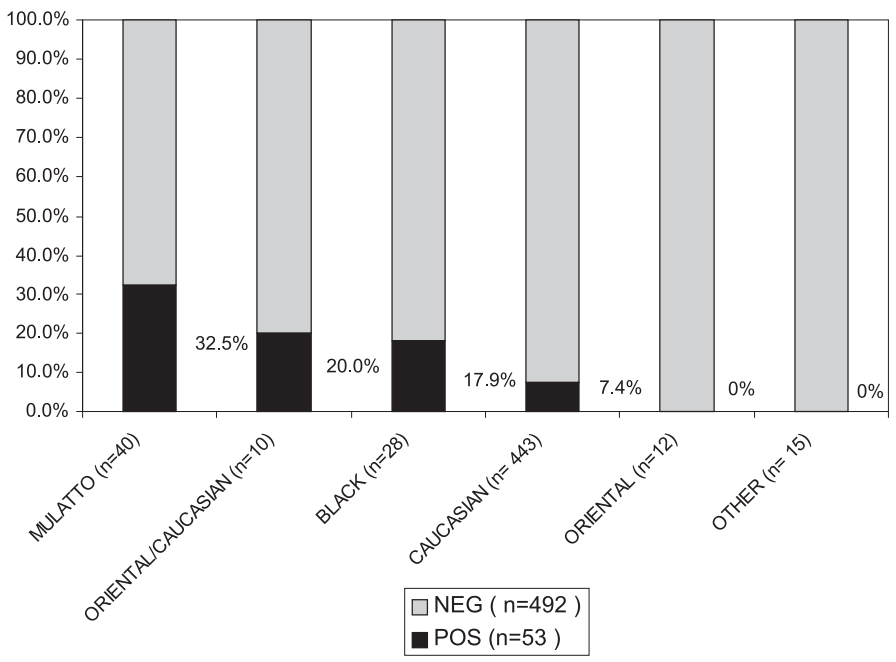

Fig. 1 - HGV-RNA prevalence by ethnic group 
Table 3

Prevalence of HGV-RNA by sex, race, education and age and statistical analysis

\begin{tabular}{|c|c|c|c|c|c|}
\hline Variable & HGV-RNA + $(\%)$ & Total & OR & $95 \%$ C.I. & p-value \\
\hline \multicolumn{6}{|l|}{ SEX } \\
\hline Female & $12(7.3)$ & 165 & 0.6 & $0.3 ; 1.3$ & 0.203 \\
\hline Male & $41(10.8)$ & 380 & - & & \\
\hline \multicolumn{6}{|l|}{ RACE } \\
\hline Black/Mulatto & $18(26.5)$ & 68 & 4.5 & $2.3 ; 8.7$ & $<0.001$ \\
\hline Caucasian & $33(7.5)$ & 443 & - & & \\
\hline \multicolumn{6}{|c|}{ EDUCATION (yr) } \\
\hline$\leq 4$ & 18 (14.8) & 122 & 2.3 & $1.1 ; 4.8$ & $0.022 *$ \\
\hline $5-8$ & $18(9.6)$ & 187 & 1.4 & $0.7 ; 2.9$ & \\
\hline$\geq 9$ & $15(6.9)$ & 217 & - & & \\
\hline \multicolumn{6}{|l|}{$\mathrm{AGE}^{\star}$} \\
\hline $18-25$ & $14(8.9)$ & 158 & 1.8 & $0.6 ; 4.7$ & 0.149 \\
\hline $26-33$ & $21(13.5)$ & 155 & 2.8 & $1.1 ; 7.3$ & \\
\hline $34-41$ & $12(10.3)$ & 116 & 2.1 & $0.7 ; 5.7$ & \\
\hline $41-50$ & $6(9.4)$ & 64 & 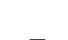 & & \\
\hline $51-59$ & $0(0.0)$ & 50 & & & \\
\hline
\end{tabular}

$*$ p-value for a $\chi^{2}{ }_{\text {trend; }}^{*}$ for the purpose of p-value and OR estimation, 41-50 and 51-59 groups were combined.

\section{DISCUSSION}

We have found a very high prevalence of HGV-RNA in our blood donor population, corroborating the data from BASSIT et al. ${ }^{3}$ on a blood donor population from another hospital in São Paulo. A prevalence of this magnitude has only been reported, to our knowledge, on West African residents and South African blood donors ${ }^{4,5}$, except for parenterally exposed groups where even higher prevalences are observed ${ }^{4,15}$. The finding of this virus in that proportion of blood donors with no correlation to other markers points to the little pathogenicity of this agent, if any. However, the determinants of these high infectious rates are so far not known. It is demonstrated the transmissibility of $\mathrm{HGV}$ by blood transfusion, hemoderivates and needle sharing but these sources of risk can't be responsible for the $10 \%$ prevalence on the general population. Mother to infant ${ }^{8}$ and close sexual ${ }^{13,14,15}$ contact transmission are currently thought to contribute most to the high prevalence seen worldwide. Though we haven't collected data concerning sexual activity of donors, in our series there was no association between HGV-RNA carrier state and more established markers of risky sexual behavior like HBsAg and anti-HIV (Table 1). However, a recently published cross-sectional study conducted with residents in the city of São Paulo detected an association between HGV and the number of sexual partners ${ }^{13}$. We haven't observed an association between HGV presence and elevation of ALT, corroborating that, to the healthy host, HGV causes no detectable hepatic damage.

An important issue in estimating an infectious agent prevalence by PCR is the choice of the primer system. We observed that primers spanning the 5'NCR detected more viremic donors than the NS3 nestedPCR, suggesting that HGV may be commonly present in a high viral load on the donor blood (Table 2) and analogously to HCV, the 5'NCR is conserved among isolates being the target of choice for PCR detection.

Among several sociodemographic variables studied, we observed a positive association with black race and a trend to higher positivity on donors reporting lower educational background. A significant association with black race has also been observed in South African blood donors ${ }^{4}$, although the factors for these racial differences are not known. It might be noted that we found an odds ratio of 4.5 of black/mulatto race over Caucasians, taking the latter as reference, but the prevalence on our Caucasian population is very high as well (7.5\%), suggesting that this group is also exposed to the factor(s) responsible for the high prevalence of HGV-RNA in the general population. It should be pointed that this association remains statistically significant even after controlling for educational level $(\mathrm{OR}=3.2,95 \% \mathrm{CI} 1.6 ; 6.6)$, what was necessary since statistical analysis showed a trend for black/mulatto donors to have fewer years of education $\left(\chi^{2}\right.$ for trend $\left.\mathrm{p}<0.001\right)$.

It is known that viremic carriers represent only part of the exposed individuals, after the report that an antibody against the putative viral envelope (E2) protein correlates to virus clearance, i.e. absence of HGV$\mathrm{RNA}^{16}$, and was shown to be present on a prevalence 2-3 times that of the PCR positive hosts. If this proportion proves to stand likewise to the population here studied, we could get to a $100 \%$ exposition rate on certain groups.

Phylogenetic analysis identified among Brazilian donors genotypes 1a, 1b, $2 \mathrm{~b}$ and 3, according to the classification proposed by MUERHOFF et al. ${ }^{10}$. In contrast to reports from other populations ${ }^{19}$, "Brazilian" HGV isolates here described are not clustered, since they present higher sequence identity to isolates from USA, Japan, Germany and West Africa than to other Brazilian isolates, possibly reflecting the racial mixed composition of the Brazilian population. Alternatively, this may be due to the low number of isolates analyzed (nine). Isolate g87958 is placed on a separate branch of the tree (Fig. 2). In depth inspection of the alignment shows that this isolate probably represents a recombinant between genotype 1a and 2a since it harbors 5'NCR motifs from both genotypes. This can be due either by an amplification artifact or a genuine in vivo recombination, as observed on a Chinese isolate ${ }^{2}$. 


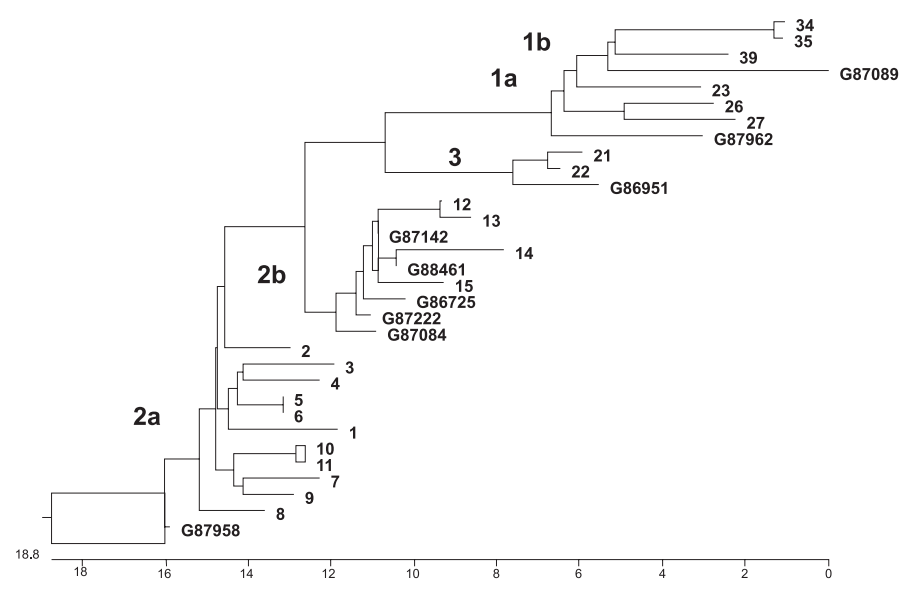

Fig. 2 - Phylogenetic tree constructed by the neighbor-joining method with DNA sequences of 340 bp (position -490 to -150 ) from the HGV 5'non-coding region from 9 "Brazilian" isolates and others representing distinct geographic regions and HGV subtypes, as proposed by MUERHOFF et al. ${ }^{10}$. Horizontal bar below represents percentage of nucleotide sequence divergence among isolates. Isolates identified by Arabic numbers are the same as they appear on reference 10 while those beginning with a $\mathrm{G}$ are from this work. Corresponding GenBank accession numbers are as follows: G87142 - AF140037; G87222 - AF140038; G87958 AF140039; G87962 - AF140040; G88461 - AF140041; G86725 - AF139620; G86739 AF139621; G86951 - AF139622; G87084 - AF139623; G87089 - AF139624

\section{RESUMO}

\section{Alta prevalência do RNA do vírus da hepatite G (HGV) em doadores de sangue brasileiros}

O objetivo deste estudo foi investigar a presença do vírus da hepatite $\mathrm{G}$ e sua associação com variáveis sóciodemográficas em uma população de doadores de sangue da cidade de São Paulo, Brasil. Dois sistemas de PCR foram empregados, um focando a região 5 ' não-codificadora e outro a região não-estrutural 3 , apresentando o primeiro maior sensibilidade.

A prevalência detectada do HGV-RNA em 545 doadores foi de 9,7\% (IC 95\% 7,4;12,5). A prevalência do HGV-RNA foi significativamente maior em doadores da raça negra/mulata $(26,5 \%)$ quando comparados aos doadores caucasianos $(7,5 \%),(\mathrm{OR}=4,5)$. Também foi observada uma tendência de maiores prevalências em doadores de menor escolaridade. Não se observou associação significativa com outros parâmetros estudados como idade, sexo, origem geográfica e local de residência.

O sequenciamento do DNA de nove isolados selecionados ao acaso demonstrou a presença dos genótipos 1, 2 e 3, mas não houve um agrupamento das amostras brasileiras quando submetidas à análise filogenética.

\section{REFERENCES}

1. ALTER, H.J.; NAKATSUJI, Y.; MELPOLDER, J. et al. - The incidence of transfusionassociated hepatitis $\mathrm{G}$ virus infection and its relation to liver disease. New Engl. J. Med., 336: 747-754, 1997.

2. AN, P.; WEI, L.; WU, X. et al. - Evolutionary analysis of the 5'-terminal region of hepatitis G virus isolated from different regions in China. J. gen. Virol., 78: 24772482, 1997.
3. BASSIT, L.; KLETER, B.; RIBEIRO DOS SANTOS, G. et al. - Hepatitis G virus: prevalence and sequence analysis in blood donors of São Paulo. Vox Sang. (Basel), 74: $83-87,1998$

4. CASTELING, A.; SONG, E.; SIM, J. et al. - GB virus C prevalence in blood donors and high risk groups for parenterally transmitted agents from Gauteng, South Africa. J. med. Virol., 55: 103-108, 1998.

5. DAWSON, G.J.; SCHLAUDER, G.G.; PILOT-MATIAS, T.J. et al. - Prevalence studies of GB virus-C infection using reverse transcriptase-polymerase chain reaction. J. med. Virol., 50: 97-103, 1996.

6. HOSMER Jr., D.M. \& LEMESHOW, S. - Applied logistic regression. New York. John Wiley, 1989.

7. KLEINMAN, S. - Hepatitis G virus biology, epidemiology, and clinical manifestations: implications for blood safety. Transfus. Med. Rev., 15: 201-212, 2001.

8. LEFRÈRE, J.-J.; SENDER, A.; MERCIER, B. et al. - High rate of GB virus type C/ HGV transmission from mother to infant: possible implications for the prevalence of infection in blood donors. Transfusion, 40: 602-607, 2000.

9. MUERHOFF, A.S.; SIMONS, J.N.; ERKER, J.C.; DESAI, S.M. \& MUSHAHWAR, I.K. - Identification of conserved nucleotide sequences within the gb virus c 5'untranslated region: design of PCR primers for detection of viral RNA. J. virol. Meth., 62: 55-62, 1996.

10. MUERHOFF, A.S.; SIMONS, J.N.; LEARY, T.P. et al. - Sequence heterogeneity within the 5 '-terminal region of the hepatitis GB virus $\mathrm{C}$ genome and evidence for genotypes. J. Hepat., 25: 379-384, 1996.

11. NAITO, H.; WIN, K.M. \& ABE, K. - Identification of a novel genotype of hepatitis G virus in Southeast Asia. J. clin. Microbiol., 37: 1217-1220, 1999.

12. PICKERING, J.M.; THOMAS, H.C. \& KARAYIANNIS, P. - Genetic diversity between hepatitis G virus isolates: analysis of nucleotide variation in the NS-3 and putative “core" peptide genes. J. gen. Virol., 78: 53-60, 1997.

13. SANTOS, G.R.; NISHIYA, A.S.; NASCIMENTO, C.M.R. et al. - Prevalence of GB virus C (Hepatitis G virus) and risk factors for infection in São Paulo, Brazil. Europ. J. clin. Microbiol. infect. Dis., 21: 438-443, 2002.

14. SCALLAN, M.F.; CLUTTERBUCK, D.; JARVIS, L.M.; SCOTT, G.R. \& SIMMONDS, P. - Sexual transmission of GB virus C/hepatitis G virus. J. med. Virol., 55: 203208, 1998.

15. STARK, K.; BIENZLE, U.; HESS, G. et al. - Detection of the hepatitis G virus genome among injecting drug users, homosexual and bisexual men, and blood donors. J. infect. Dis.,174: 1320-1323, 1996.

16. TACKE, M.; KIYOSAWA, K.; STARK, K. et al. - Detection of antibodies to a putative hepatitis G virus envelope protein. Lancet, 349: 318-320, 1997.

17. THOMPSON, J.D.; HIGGINS, D.G. \& GIBSON, T.J. - CLUSTAL W: improving the sensitivity of progressive multiple sequence alignment through sequence weighting, position-specific gap penalties and weight matrix choice. Nucleic Acids Res., 22: 4673-4680, 1994.

18. TUCKER, T.J. \& SMUTS, H.E. - GBV-C/HGV genotypes: proposed nomenclature for genotypes 1-5. J. med. Virol., 62: 82-83, 2000.

19. VIAZOV, S.; RIFFELMANN, M.; KHOUDYAKOV, Y. et al. - Genetic heterogeneity of hepatitis $\mathrm{G}$ virus isolates from different parts of the world. J. gen. Virol., 78: 577 $581,1997$.

Received: 09 October 2002

Accepted: 23 January 2003 